Danijela Kambasković - Švarc

\title{
PITANJE VREMENA
}

Ovaj rad preispituje ideju i proces prolaska vremena iz perspektive fizike, književne teorije i lične istorije, primenjujući (i tom primenom dajući omaž) književnokritičkim metodama tekstualne kritike, istorije književnosti, prepeva i istorije ideja koje su označile pedagogiju na Katedri za anglistiku u Beogradu u uslovima političkih previranja ranih 90-ih godina XX veka.

Ključne reči: vreme, fizika, književna teorija, lična istorija, prepev.

\section{TEORIJA DVOSTRUKOG VREMENA}

Dogodilo se to na četvrtoj godini dodiplomskih studija na Katedri za Anglistiku u Beogradu, jednog rano-letnjeg popodneva pre dvadeset i pet godina. Pred junski rok, u Narodnoj biblioteci, spremala sam Šekspira, tada obavezni dvosemestralni predmet na četvrtoj godini dodiplomskih studija. Ispit se polagao kod profesora Veselina Kostića, tog utelotvorenja nenamernog straha i trepeta. Epifanija - trenutak kada sam spoznala da će moje životno opredeljenje biti Šekspir, istorija i književnost 17. veka - nastupila je kad se preda mnom našao članak o Otelu i teoriji dvostrukog vremena.

„Jedinstvo vremena” jedno je od osnovnih antičkih pravila dramaturgije koje su poštovali renesansni pisci: moralo se voditi računa o tome da se dramska radnja odigra u kontinuitetu, u trajanju od oko tri dana raspoređena u pet činova. Međutim, Vilson-Halpinova teorija o dvostrukom vremenu koja tvrdi da Šekspir meri vreme duplim satovima: hronološkim (istorijskim, istinskim, u kome vreme teče kao 
u stvarnom životu, sporim) i dramskim (fiktivnim, teleskopski sklopljenim i sažetim, brzim), postavljena je još krajem devetnaestog veka (FurNESS 1886: 358). Dakle, o Šekspirovom variranju pravila jedinstva vremena pisalo se još stotinak godina pre nego što sam se ja našla za sudbnosnim stolom u Narodnoj biblioteci. Ali u Otelu, odnos između hronološkog („sporog”) i dramskog („brzog”) vremena posebno je kompleksan. Šekspir ih koristi kao sredstvo manipulacije pažnje gledaoca.

Hronološko, „sporo” vreme u Otelu traje tri do četiri meseca, i može se sažeti ovako: Otelo i Dezdemona venčavaju se u Veneciji, provode jednu noć zajedno, a zatim se ukrcavaju na dva različita broda, kojim onda nekoliko nedelja plove od Venecije do Kipra. Brod sa Otelom stiže na Kipar pre broda sa Dezdemonom. Po Dezdemoninom dolasku, Otelo i ona žive na Kipru neko vreme; pod zlim uticajem Jaga, njihova nesloga polako raste (trajanje: bar nekoliko nedelja). Iako se bitke ne pominju eksplicitno, Otelo je kao general morao rukovoditi nekolikim bitkama (trajanje: bar nekoliko nedelja), jer se vest o njegovom vojnom neuspehu proširila do Venecije (trajanje: nekoliko nedelja brodom od Kipra do Venecije ili prvo brodom, a onda konjem preko Balkana). Poslanici dolaze na Kipar da sa njim razgovaraju o tim neuspesima (trajanje: još nekoliko nedelja da poslanici stignu iz Venecije na Kipar). Dakle „sporo” vreme u drami traje bar tri do četiri meseca.

Dramsko ili „brzo” vreme, međutim, opisano je tako da ga pratimo od sklapanja braka Otela i Dezdemone, pa do ubistva, u trajanju od tri dana u kontinuitetu (SProule 1956: 217-226), baš kako i treba ako dramski pisac poštuje antičko pravilo „jedinstva vremena”. Otelo i Dezdemona venčavaju se u Veneciji i provode jednu noć zajedno (trajanje: dan i po). Po dolasku na Kipar, Otelo i Dezdemona provode kratko vreme zajedno. Pod Jagovim uticajem loši odnosi eskaliraju i do ubistva dolazi druge noći na Kipru (trajanje ove faze: dan i po. Ukupno trajanje radnje: tri dana).

Šekspir manipuliše našom pažnjom, upravlja dvostrukim vremenom takvom veštinom, radnja tako neumitno hrli ka svom tragičnom 
raspletu, da se ni Otelo ni gledalac ni jednog trenutka ne prisete ključnih činjenica koje je Šekspir brižljivo uneo u tekst i učinio jasno vidljivim: Dezdemona i Kasije nisu putovali od Venecije do Kipra na istom brodu, tako da se preljuba nije mogla odigrati u Otelovom odsustvu; Emilija nikad ne napušta Dezdemonu kad je sa Kasijem, tako da se preljuba nije mogla odigrati u zamku; a dramska radnja na samom ostrvu traje prekratko da bi do zavođenja realno moglo doći. Jednostavno nije bilo vremena da se preljuba dogodi.

„Brzim” dramskim vremenom od tri dana, Šekspir vrši pritisak ne samo na gledaoca već i na samog protagonistu, Otela. Mogućnost Dezdemonine prevare ostaje uverljiva samo zato što su i Otelo i gledalac zaslepljeni Šekspirovom umetničkom manipulacijom protoka vremena.

Trebalo mi je malo vremena da ovo shvatim. Kad sam shvatila, sedela sam neko vreme, zanemela, u Narodnoj biblioteci, i zurila u fotokopiju kritičkog teksta.

„Želim ja da budem ta koja će da čita Šekspira i pronalazi ovakve stvari”, pomislila sam.

I to je bilo to. Odluka je bila doneta.

U trenutku epifanije, bio je u toku moj osmi sat u biblioteci. To je bila moja standardna „šihta”. Često sam zaboravljala da ručam, a o inflaciji koja je divljala van Biblioteke, praznim supermarketima i sankcijama nisam razmišljala. Osam sati radnog dana danas mi traje mnogo duže, iako sa većim pauzama. Vreme teče sve brže, iako su sati dosadniji. Veoma mi je važno kakva je inflacija, a ručak nikad ne zaboravljam. Manipulaciju moje percepcije vremena vršila je široka budućnost, koja je tada još bila preda mnom.

\section{DUH VREMENA I VREMEPLOV}

U vreme mojih dodiplomskih studija, velike, nove teme koje su dolazile iz savremene anglofone književne kritike bile su fiktokritika - postmodernistički, eksperimentalni, često feministički pristup knji- 
ževnoj kritici koji kombinuje elemente tradicionalnih književnih kategorija (fikcije, teorije i kritike) u jedinstveni tekst; i autobiografska kritika, metod koji fiktokritici dodaje i autobiografske elemente ${ }^{1}$. Uz Šekspira, dramu i poeziju Tjudora, opsedali su me renesansna istorija Engleske i moderna književnost Engleske i Novog sveta. Kasnije ću napraviti „pauzu” u studijama književnosti 17. veka da bih napisala magistarsku tezu o recepciji australijske književnosti u Jugoslaviji, uz mentora profesora Svetozara Ignjačevića (vidi: Kombaskovic-Soers 2015). Gutala sam sve što je ukazivalo na prošlost, ali i na sadašnjost na nekom drugom mestu. Ta vrsta žeđi bila je svojstvena čitavoj našoj generaciji.

U zemlji, isti period bio je obeležen društvenim previranjima. Iako sam geografsku lokaciju upisa promenila tek u vreme doktorata, studije sam upisala u jednoj državi, obavljala u drugoj a završila u trećoj. Na trećoj godini ostavila sam studije i sa dečkom pobegla u Grčku (tada zamamnu, bogatu zapadnu zemlju punu mandarina, kivija, koji sam tada prvi put videla, i Milka čokolade pakovane u, našim izgladnelim očima, neodoljiva srebrnasta pakovanja). Vratili smo se za manje od mesec dana jer moj dečko nije u tom, za zemlju teškom trenutku mogao da izdrži emotivni pritisak pečalbe, ali taj prekid pamtim kao trenutak koji je bilo najteže premostiti povratkom na studije. Povratak mi nije nimalo olakšala činjenica da je prvi ispit koji je trebalo položiti po povratku bio Kontrastivna analiza engleskog i srpskog jezika, najobimniji, najdetaljniji i najnepotrebniji predmet u istoriji čovečanstva. Bilo je to na četvrtoj godini dodiplomskih studija, a godina je bila 1993. Trenutak je bio između pada Vukovara i najžešćih sukoba u Bosni, usred sankcija protiv Srbije. Seminarski radovi još uvek su se (mada ne zadugo!) pisali na pisaćoj mašini. Inflacija je divljala, supermarketi zvrjali prazni (mislim da bi današnjoj mladeži bilo teško da ovo zamisle). Aerodrom je bio zatvoren. U svemu tome, nepravda koja me je najžešće pekla bila je to što je međubibliotečka razmena bila obustavljena pravilnikom o sankcijama. Ipak smo mi bili mladi ljudi,

1 Ovaj članak pišem ovim metodama, namenjenim poduci putem književne identifikacije, u znak trajog poštovanja katedri na kojoj sam ih naučila. 
studenti koji ni mrava nisu zgazili, a kamoli vodili ratove. Čitav svoj mladi vek moja generacija studenata posvetila je književnosti i istoriji upravo onih nacija koje su nas kaznile odsecanjem međubibliotečke razmene, i na još mnogo načina.

Tek danas, decenijama kasnije, dozvoljavam sebi da dam glasa toj traumi. Do danas se nisam usudila to ni da izgovorim, jer nije bilo u redu patiti zbog ukidanja međubibliotečke razmene, dok su drugi, manje srećni ljudi u našoj bivšoj, nesrećnoj zemlji svakodnevno ginuli. Nisam se pitala o uticaju dugoročne neizrečene krivice bez krivice. O tome se pitam tek sad, kad sam pročitala radove o uticaju „krivice preživelih", o pravilima za oproštaj (BALINT et al. 2014: 194-216), napisane razmatrajući sudbine drugih nacija. I onda kad svoju mladu kćerku od trinaest godina, Australijanku, zamišljam u toj hipotetičnoj situaciji.

U Australiji su me često pitali: kako to da je neko ko je živeo u Miloševićevoj Srbiji uopšte mogao da se zanima za šesnaesti i sedamnaesti vek u Engleskoj? (U tom se pitanju može naslutiti loše skriveno kolonijalno iznenađenje. Drugim rečima, „kako to da neko ko nije rodom anglofon može da predaje Šekspira Australijancima?” ili, „Uspeh psa koji hoda na dve noge, naravno, nije u tome što to čini dobro, već što to uopšte čini””) (Boswell 1844: 205-6). U pitanju je, naravno, bila jedna vrsta eskapizma. Ali osnovno značenje tog pojma - beg u uživanje - nedovoljan je da bi objasnio moje opredeljenje. Na stranu to što mislim da upravo samo onaj ko je autsajder može ispravno da predaje Otela, Šajloka, Kalibana (Bura) ili Arona (Tit Andronik). Mislim da je važnija odlika mog eskapizma to što me je rad na Šekspiru kao mladu osobu izlagao ljudskim spletkama na nivou državnosti, kao i međuljudskih odnosa, dovoljno kompleksnim da skrenu pažnju sa bizarnih spletki i korumpiranosti koje su odredivale moju svakodnevnicu, i dovoljno davnašnjim da bi ih postavili u istorijsku ravan.

2 "Sir, a woman's preaching is like a dog's walking on his hind legs. It is not done well; but you are surprised to find it done at all." 
Izloženost modernim strujama u književnosti takođe je normalizovala mesto intelektualne debate o pitanjima koja nisu vezana za hegemoniju i etničke interese. Već i sama svest o tome da negde ljudi misle o stvarima kao što su mesto žena u književnoj istoriji ili pitanja teorije i izraza, a ne o ratnoj osveti ili podeli teritorija, bila je dovoljna da povrati bar deo izgubljene perspektive. I na kraju, i sam proces težnje ka kvalitetnom pisanju na dva jezika bio je lekovit. S jedne strane, učenje stranog jezika je jedan način da se utišaju reči na sopstvenom. (Ovo je tada bilo lekovito, ali je do posebno gorkog izraza došlo kasnije, u emigraciji.)
Jezik koji učih ovih četrdeset godina,
Svoj maternji engleski, napustiti moram:
Od svog jezika imaću koristi
koliko i od harfe ili viole bez žica,
od skupog instrumenta u kovčegu,
ili pak u rukama nekog ko harmoniju ne razume.
Moja ste usta u zatvor mom jeziku pretvorili,
Zaključanom iza dvostrukih rešetaka zuba i usana;
I bezumno, nemo, jalovo neznanje
Pored mene vazda stražariće. ${ }^{3}$

Takođe lekovita bila je mukotrpna izgradnja rečenica, koje su, pre nego što se zapišu, satkane od titravih, kaleidoskopskih ideja kojima uvek - a pogotovo u mladosti - nedostaje samosvesti. Lako ih je raspršiti pre nego što su zapisane. Tek se pomnim uglavljivanjem u rečenicu otelotvoruju i dobijaju na težini. Zapisivali smo ih s neveri-

3 Sve citate u ovom eseju prevela sa engleskog Danijela Kambasković Švarc. "The language I have learn'd these forty years/ My native English, now I must forego: / And now my tongue's use is to me no more / Than an unstring'd viol or a harp, / Or like a cunning instrument cased up, / Or, being open, put into his hands/ That knows no touch to tune the harmony;/ Within my mouth you have engaol'd my tongue, / Doubly portcullis'd with my teeth and lips;/ And dull unfeeling barren ignorance/ Is made my gaoler to attend on me". William, Shakespeare, The Tragedy of King Richard The Second, Act 1, Scene 3, 11. 153-64, in Greenblatt, Stephen et al. (eds.), The Norton Shakespeare, Oxford: Oxford University Press, 2008, 973-1046. Svi citati Šekspirovih dela u ovom eseju potiču iz ovog izdanja. 
com i izvinjavajućim izrazom lica, a njihov smisao nazreli godinama kasnije.

...oči stvaraoca, dok ih u prefinjenoj ludosti prevrće,
Prelaze sa zemlje na nebo, sa neba na zemlju,
i dok mu maštom plove
seni nepoznatih stvari, on ih perom
uobličava, i vazdušastom ništavilu
daje konkretno stanište i ime ${ }^{4}$.

Prve magistarske studije koje sam upisala (teatrologija na Akademiji dramskih umetnosti, (1995-6) bile su obeležene egzodusom Srba iz Hrvatske, studentskim protestima i mojim plaćeništvom u stranim izbegličkim agencijama u Beogradu. Položila sam sve ispite, ali nikad nisam dovršila tezu. Bilo je preteško učiti u tim uslovima, i ja sam odustala. Onda sam jednog dana, na Filološkom fakultetu, u prolazu, srela profesora Veselina Kostića, tada već u penziji. Kada je čuo da sam prestala da studiram, nije me grdio kao što sam očekivala. Nije govorio o duhu vremena. Rekao je jednostavno: „Pa naravno da ste prestali, kad ste se udaljili od teksta. Kakva predstava, molim vas. Koliko ja vas poznajem, vama treba tekst. Vratite se tekstu." Otišla sam kući i isplakala se. Da mi je bilo ko drugi rekao da batalim pet položenih ispita pred tezu, i počnem ponovo, ne bih slušala, ali njega sam poslušala. Iako sam tim potezom izgubila državnu stipendiju i stavila svoj materijalni život na milost i nemilost ekonomije razmene rada, upisala sam druge magistarske studije, Nauku o književnosti, i počela sve iz početka povratkom tekstu.

4 "The poet's eye, in a fine frenzy rolling, / doth glace from Heaven to Earth, from Earth to Heaven, /And as imagination bodies forth/The forms of things unknown, the poet's pen/ Turns them to shapes and gives to airy nothing/ A local habitation and a name." Shakespeare, William, A Midsummer Night's Dream, 839-896, Act 5, Scene 1, ll. 12-17. Originalnu reč „poet”, „pesnik”, prevela sam ovde kao „stvaralac” zbog kontekstualne tačnosti, a i zbog toga što starogrčka reč "poiesis" označava svakoliko, ne samo poetsko, stvaralaštvo. 
Šekspir i poezija Tjudora hranili su svest o jednoj drugačijoj lepoti, lepoti punijoj od larpurlartizma ili hedonizma: lepoti uzdizanja iznad sopstvenih uskih interesa i misli. Otkrila sam da je za očekivanje da oni, čija je svest povređena i poverenje poniženo, postanu žrtve (Ofelija u Hamletu, Lukrecija u Nasilju nad Lukrecijom, starija braća u Ričardu Trećem), ili silnici koji, sa više ili manje olakšavajućih okolonosti, kasnije i sami drugima čine zlo (Otelo, Šajlok iz Mletačkog trgovca, Tamora iz Tita Andronika). Saznala sam da postoje različite vrste nasilja nad ženama: nasilje na mah - strasno, neposredno (Otelo) i promišljeno, hladno, posredno (Zimska bajka). Sekspir je nudio put izdizanja iz intelektualnog i et(n)ičkog jednoumlja, koliko god pravoverno ono bilo. Ljubav pobeđuje dva suprotstavljena pravoverja (i otkriva glupost vere u pravoverje a iznad ljudskosti) u Romeu $i$ Juliji. Hamlet se bori protiv prevlasti javnog svetonazora. Pitanje izbeglica i saosećanja s njima sreće se u Tomasu Moru, podsećajući na ljudsku odgovornost široj moralnosti većoj od ličnih interesa:

Zamislite da ih uklone, i zamislite da ta vaša buka bude jača i od kraljevske vlasti u Engleskoj.

Zamislite onda te bedne strance,

Sa bebama privijenim na leđa, sa dronjavim prtljagom, kako teška koraka idu ka luci da ih deportuju, a vi sedite kao kraljevi posred onog što ste želeli, ogrnuti plaštom svojih nazora.

Sta onda imate? E da vam ja kažem. Pokazali ste Da bezobrazluk i snaga pobeđuju, dok su red i mir nevažni. Kad bi stvari tako išle, ni jedan od vas ne bi starost doživeo,

a da se neki drugi grubijan, onako kako njegova želja njega vuče, istim buzdovanom, istim razlozima i istim pravoverjem opasan, ne okrene kao ajkula protiv vas, i da se ljudi kao izgladnele ribe jedni drugima nahrane. Zamislite da kralj 
Danijela Kambasković - Švarc: Pitanje vremena

čuje za vaš prestup, pa vas progna, kud bi onda išli?

Koja bi onda zemlja, prema vašim sopstvenim iskrivljenim nazorima,

trebalo da vam pruži utočište?

Da odete u Francusku, Flandriju,

ma koju provinciju Nemačke, Spaniju ili Portugal,

bilo gde, a da se sa Engleskom ne graniči,

Tad morali biste i vi biti stranci. Da li bi vam odgovaralo

da naiđete na naciju čija je narav tako varvarska

da vam, pod okriljem sramne tišine

odbije odstupnicu na zemlji,

da vas, s odvratnim noževima pod grlom

kao pse prezre, kao da taj Bog

nije i vas stvorio i decom zvao, kao da vi na pomoć koju

tražite

nemate pravo, već da vam se mora naplatiti,

šta bi vi rekli, da se prema vama neko tako ponaša?

E, to je argument ovih stranaca;

to je nehumanost vaša, kao planina nepregledna. ${ }^{5}$

5 Grant them removed, and grant that this your noise / Hath chid down all the majesty of England; / Imagine that you see the wretched strangers / Their babies at their backs and their poor luggage,/Plodding to the ports and coasts for transportation, And that you sit as kings in your desires, ...And you in ruff of your opinions clothed;/ What had you got? Ill tell you. You had taught How insolence and strong hand should prevail, / How order should be quelled. And by this pattern / Not one of you should live an aged man,/ For other ruffians, as their fancies wrought, / With self same hand, self reasons, and selfright, / Would shark on you, and men like ravenous fishes / Would feed on one another ... Say now the king .../ Should so much come to short of your great trespass / As but to banish you, whither would you go?/ What country, by the nature of your error, / Should give you harbour? Go you to France or Flanders,/ To any German province, to Spain or Portugal, / Nay, any where that not adheres to England, Why, you must needs be strangers. Would you be pleased/ To find a nation of such barbarous temper, That, breaking out in hideous violence,/ Would not afford you an abode on earth, / Whet their detested knives against your throats,/ Spurn you like dogs, and like as if that God / Owed not nor made not you, nor that the claimants/ Were not all appropriate to your comforts, / But chartered unto them, what would you think/ To be thus used? This is the strangers' case;/ And this your mountain- 
Subverzija i rušenje pravila na oltaru uverenja u dobrotu ljudi tema je koja se provlači kroz Kako vam drago, Sve je dobro što se dobro svrši, Julija Cezara. Gotovo beslovesna velikodušnost pojavljuje se kao jedna od najvažnijih vrednosti (Antonije i Kleopatra,Zimska bajka, Soneti). Sve ovo predstavljalo je za mene izvor vere u ljude i u budućnost, u odsustvu takvih uzora u stvarnom životu. Put teorije uma (kojom se tvrdi da ljudsko biće može da razume kako se drugi oseća na osnovu sličnosti sa sopstvenim reakcijama, i da tako uči da u kasnjem životu izbegava da čini ono što njega samog uznemirava, da bi izbegao uznemirenje drugih) formirao se u mom životu uz Šekspira. On to nije činio, kao oni u stvarnom životu oko mene, proklamatorskim idejama, već odsjajima značenja iz predstave kompleksnih odnosa i večitom svežinom nenadanog uvida. Realnost nas je tretirala kao naivnu decu, a Šekspir kao mudre, ili bar potencijalno mudre, odrasle.

Moje druge magistarske studije, ovog puta filologije, po savetu profesora Kostića, protekle su u znaku Miloševićevog pogroma akademskih nepristalica i bombardovanja Beograda. U ovo vreme već sam živela u inostranstvu i putovala u Beograd na polaganje ispita i pisanje teze. Jedan od ispita polagala sam tajno, usred zime, u negrejanoj zgradi Fakulteta. Cinjenica da se ispit uopšte odigrao imam da zahvalim širokogrudosti renomiranog (nedavno preminulog) profesora koji je odbio da potpiše lojalnost Miloševiću i izgubio posao, a kome je, nakon toga, katedra na kojoj je radio iskazivala solidarnost prekidom ispita i predavanja od nekoliko meseci. U svojoj teškoj situaciji, on je našao vremena i prostora da me sasluša. Zbog ličnih okolnosti, u Beograd sam na ispit iz Australije doputovala tada, a ispitni rok je naglo prekinut nakon mog dolaska. Nisam mogla da odletim, pa da doletim kasnije. Predložila sam profesoru - mimo svake nade - da se ispit obavi tajno, s tim da se protest poštuje tako što bi ocena u indeks bila uneta tek kasnije, po završetku protesta. Renomirani profesor odmah je uvideo da je jedino što tražim mogućnost da budem ispitana, a ne specijalni tretman po pitanju ishoda ispita. Na predlog je pristao,

ish inhumanity. Shakespeare, William, Sir Thomas More, Act 2, Scene 4, lines $55-124$. 
nazvao kolegu i lično ga zamolio da me tajno ispita i da nikom ništa ne govori.

I tako sam se ja, u neverici, potpuno sama, našla u negrejanom kabinetu zatvorenog Fakulteta, uz namrštenog, ćutljivog, smrznutog predmetnog profesora. Oboje smo bili u dugim zimskim kaputima, sa šalovima i rukavicama. Predmetni profesor me je prostrelio očima i bez reči mi uručio pitanja. Seli smo na dva kraja njegovog radnog stola. Ja sam skinula jednu svoju rukavicu da pišem; on svoje nije skinuo. Ja sam škrabala ispit, on je čitao knjigu. Nakon tačno devedeset minuta me prekinuo i poslao da prošetam Knez Mihajlovom dok on rad ne pročita i ne oceni, rekavši da ću, u slučaju da sam položila, odmah polagati i usmeni. (Ne treba govoriti kako je to teško učiniti u istom danu, a pogotovo u situaciji ekstremne hladnoće, nejela i neizdrživog emotivnog pritiska). Ali kada sam se vratila nakon dvadeset minuta, na profesorovom licu zatekla sam majušni osmeh. Sećanje na taj osmeh je za mene i do dan-danas najuzbudljiviji intelektualni kompliment, jer on je značio da je u mom pismenom radu profesor našao nešto zbog čega je na trenutak zaboravio i deranžman, hladnoću, i mrzovolju povodom situacije u koju se našao upleten, i neprijatnost potencijalnog nesporazuma i optužbe za štrajkbreherstvo. Usmeni ispit sam polagala, i ocenu usmeno dobila, na licu mesta, a upisana je tek nekoliko meseci kasnije, kada je protest bio okončan i ispitni rokovi počeli. A ja nisam morala da plaćam put iz Australije. I nikom ništa.

Oni što imaju moć da povrede, ali to ne čine ...Oni su zakoniti naslednici nebeske milosti Oni su ti koji će bogatstvo prirode sačuvati od propasti. ${ }^{6}$

Samilost po svojoj prirodi ne poznaje prisilu.

I kaplje kao nežna kiša nebeska na ono što se nađe pod njom. Oproštaj dvaput blagosilja:

6 "They that have the power to hurt and will do none/ ...They rightly do inherit heaven's graces/ And husband nature's riches from expense”. Shakespeare, William, Sonnet 94: 1-6, The Sonnets, 1937-1999. 
prvo onoga koji ga daje, onda onoga ko ga prima;

Moćan je kad od moćnih dolazi, i priliči

ustoličenom monarhu bolje od krune.?

Ljudska dobrota, širokogrudost, razumevanje ličnih odnosa i kompleksnosti situacije prevladale su pravila, a jedna mlada Beograđanka otišla je u svet potvrđene vere u ljude.

\section{DUBOKO VREME, VREME-PROSTOR I POZICIJA POSMATRAČA U TEORIJI RELATIVITETA}

Prema konkordansi Šekspirovih dela, vreme se u Šekspirovom opusu pominje 1100 puta. Najmanje se pominje u Veneri $i$ Adonisu, četiri puta (što možda nije za čuđenje, ne samo zato što je delo relativno kratko, niti zato što je mladalačko, već i zato što se fokusira na ljubavnu igru u kojoj se vreme zaboravlja) pa do 41 pomena u Sonetima, delu u kome je sposobnost umetnosti da omogući umetniku besmrtnost jedna od najvažnijih tema. Drame u kojima se vreme najčešće pominje su Simbelin i Hamlet (40 puta), Magbet (39 puta) i Ričard Treći (34 puta). Sve ove drame na različit način pristupaju dejstvu vremena na sile u ličnom i društvenom života i borbi dobra i zla. Ili, preciznije, onog što doživljavamo kao dobro i zlo, ograničeni svojom ličnom perspektivom:

Jer ničega nema, ni dobrog ni lošeg, a da ga mišljenje takvim ne čini. ${ }^{8}$

Duboko vreme je koncept koji je, krajem devetnaestog veka (istina, ime je dobio tek kasnije) ljudima prvi put promenio poimanje sopstvenog

$\gamma$ "The quality of mercy is not strained. / It droppeth as the gentle rain from heaven/ Upon the place beneath. It is twice blest; / It blesseth him that gives an him that takes: "Tis mightiest in the mightiest; it becomes/ the throned monarch better than his crown. Shakespeare, William, The Comical History of The Merchant of Venice, or Otherwise Called The Jew of Venice (pp. 1111-1176), Act 4, Scene 1, ll. 179-184.

8 William, Shakespeare, The Tragedy of Hamlet, Prince of Denmark, 1683-1784, Act 2, Scene 2, 1l. 244-5. 
istorijskog identiteta objasnivši da su geologija Zemlje, život i ljudska zajednica nepojamno stari, milionima godina stariji nego što se do tada verovalo. Identitetska nesigurnost izazvana promenom poimanja mesta čovečanstva u istoriji Zemlje (odnosno spoznaja o relativnoj beznačajnosti uloge čoveka i poricanje biblijskih mernih modela) bila je slične razorne snage kao promena koja je nastupila sredinom sedamnaestog veka, kad je kopernikanski heliocentrični model konačno prevazišao ptolomejski, geocentrični sistem, i ljudima prvi put skrenuo pažnju na „beznačajnost” Zemlje u svemirskom poretku. Na sličan način, student engleskog jezika i književnosti obrazovan van anglofonog edukativnog sistema veruje u superiornost tog sistema, da bi, dolaskom u anglofoni sistem, izgubio svoju duboku aspiraciju shvativši da su i kvalitet nastavnog programa i podrška i vrednovanje ljudi, u velikoj većini slučajeva, na daleko nižem nivou no u sistemu od koga su pobegli. Istina, više se zarađuje, ali je zbog visokih cena kvalitet života daleko niži od onog od koga su otišli. Vremenom, shvataju da su oni koji su ostali doneli bolju odluku, iako to, zaslepljeni sopstvenim problemima u matičnoj zemlji, sami retko vide. Spoznanje o pogrešnoj životnoj investiciji donosi tektonske promene u poimanju sopstvenog identiteta.

Prema Ajnštajnovoj specijalnoj teoriji relativiteta iz 1905. godine, vreme teče drugačije u zavisnosti od pozicije sa koje se događaj u vremenu posmatra. Moj mladalački život i odrastanje čine se drugačiji kada ih posmatram iz perspektive političkih događaja koji su se tada odvijali i odredili našu budućnost. Fenomen „prostor-vreme” odlična je metafora za emigraciju. Razlike u proticanju vremena nevidljive su neposrednim posmatranjem i iz perspektive onih koji su ostali u zemlji, ali i onih koji su emigrirali sve dok su u svojoj novoj zemlji. Razlike u poimanju fenomena prostor-vreme ukazuju se tek po povratku ili pri komunikaciji sa starim prijateljima. Polarizacija političkih mišljenja i ostalih životnih nazora, nastala u odsustvu između prijatelja koji su nekada imali slična mišljenja, ponekad je dovoljno snažna da ta prijateljstva naruši. 
Domaći emigrantima prebacuju naivnost i nerazumevanje domaće situacije. Emigranti domaćima prebacuju bezosećajnost i nedostatak suptilnosti. Politička mišljenja počinju da se razilaze. Oni koji žive u kapitalizmu počinju da cene aspekte socijalizma čiji nestanak ima višestruk uticaj na njihove živote, a oni koji žive s ostacima socijalizma čeznu za kapitalizmom kao lekom za sve društvene bolesti. Oni koji više nemaju pristupa tradicionalnoj domaćoj hrani glorifikuju nekadašnji način života. Oni koji imaju pristupa domaćoj hrani smatraju je nevažnom i nevrednom razgovora. Zlatno englesko pravilo lepog ponašanja za trpezarijskim stolom jeste da se nikad ne pokreću teme seksa, religije i politike - teme neprikladne za razgovor između površnih poznanika. Stara prijateljstva domaćih i emigranata počinju tako da izgledaju, polako se svodeći na održavanje prijatnosti i pozitivnosti. Nema mesta pomenu bilo čega što je važno i suštinsko - istine, životnih teškoća, moralnih nazora, političkih stanovišta, ubeđenja. Deoba ovakvih tema je u vreme mog odrastanja bila prerogativ pravih prijatelja - za nas, emigrante, upravo ono zbog čega smo, suočeni sa površnom prijatnošću Zapada, čeznuli za prijateljima kod kuće. Te su teme i tu postale neprihvatljive. Kao u neuzvraćenoj ljubavi, mi emigranti plačemo zahtevajući nešto čega je nekad bilo, a više ga nema, i što se, naravno, ne može zahtevanjem povratiti. Polako, vremenom, između emigranata i domaćih, izbegavanje važnog postaje cena održavanja prijateljstva.

Sasvim je moguće da ova problematika postoji i nezavisno od emigracije, mada se emigracijom kristalizuje. Moguće je da je otežavajući faktor upotreba društvenih medija, koja je posebno naglašena kod emigranata, budući da društveni mediji doprinose polarizaciji već postojećih političkih grupa. Opozicionarstvo nije novi fenomen - to je osnova politike - ali polarizacija o kojoj se ovde radi ukazuje na radikalizaciju već postojećih mišljenja (drugim rečima, ako ste vegetarijanac, postaćete vegan). Diskusija na socijalnim medijima ljudima ne menja mišljenje, već izaziva dublje i strasnije pokloništvo njihovom već postojećem mišljenju. Ta polarizacija veoma je izrazita i sasvim očita na dijagramima koji pokazuju promene u polarizaciji 
javnog mnjenja od 1995. godine do danas9. Društveni mediji tome doprinose plasiranjem oglasa i mema, u koje svrhe mere mišljenja i reakcije, da bi onda preciznije upućivali sadržaje onima koji će se s njima složiti (ciljna grupa), a diskusije između ljudi na ličnim zidovima odvijaju se bez uvida u neverbalne i telesne reakcije, bez zadrški koje postoje pri ličnoj razmeni. Ipak, zadrška je pitanje manira, a mišljenje pitanje suštine. Ono što me više brine je promena suštine, a ne manira s kojima se ta suština izražava. Emigrantima ostaje da okrenu glavu od prošlosti i suoče se, hteli-ne hteli, sa sadašnjošću i budućnošću promenjene suštine. Pesma Konflikt pesnika Sesila Dej-Luisa, napisana sredinom dvadesetog veka, daje odličan izraz ovom problemu:

\section{...živeći ovde \\ živim kao neko između dve velesile, \\ koga neutralnost neće spasti \\ niti profesija radovati.}

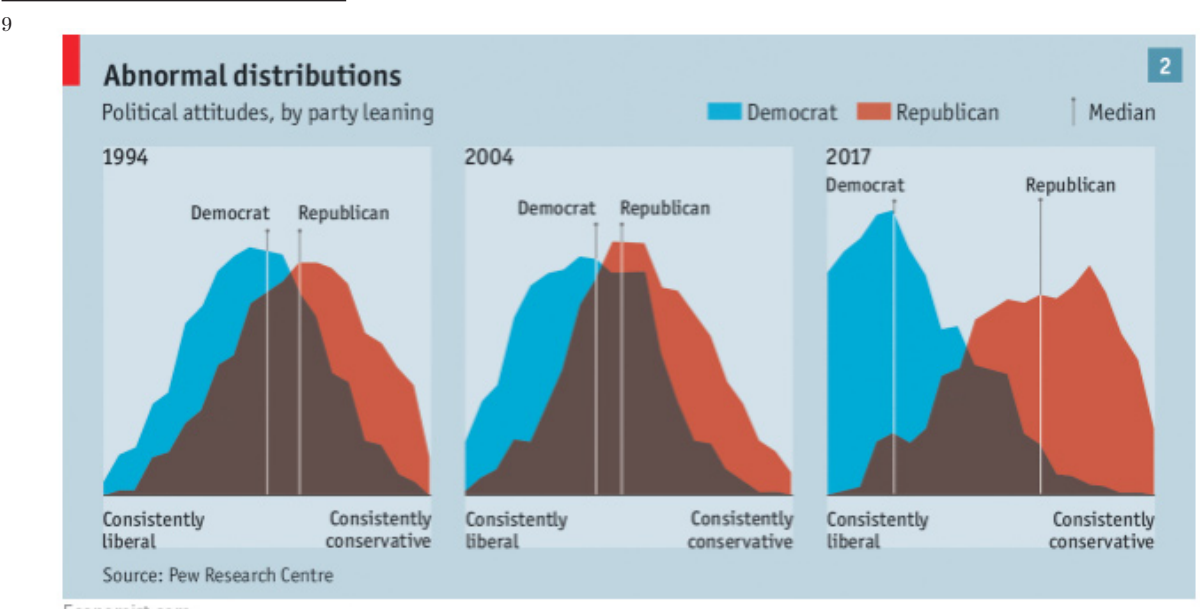

"Once considered a boon to democracy, social media have started to look like its nemesis.", The Economist, November 2017, https://www.economist.com/briefing/2017/11/04/once-considered-a-boon-to-democracy-social-media-havestarted-to-look-like-its-nemesis 
...Pokrenimo se, onda, s novim žudnjama, jer tamo, gde smo nekad gradili i voleli ničija je zemlja, a samo duhovi preživljavaju između dve vatre ${ }^{10}$.

\section{KVANTNA TEORIJA, IMAGINARNO VREME}

Kvantna teorija uvodi u fiziku nov pojam, imaginarno vreme, koje je matematička kategorija. Imaginarno vreme može se ovako predstaviti: prvo zamislimo obično, realno vreme kao horizontalnu osu na kojoj je sa leve strane prošlost a sa desne budućnost, onda treba zamisliti dodatnu dimenziju vremena, koja se kreće po vertikalnoj osi koja seče horizontalnu. Zajedno, ove ose su iskrivljene kao sedlo, i trodimenzionalne. Imaginarno vreme karakterišu paradoksi; ono ne podleže direktnom iskustvu ali postoji; nema ograničenja ali je konačno, kao površina Zemlje(Hawking 2018).

Imaginarno vreme odlična je metafora za prepev. Prepev, prevod poetskih dela, poseban je, umetnički vid prevođenja, aktivnost na rubu spiritualizma. Kao što medijum komunicira sa mrtvima, prevodilac poezije pozajmljuje svoj mozak, jezik i umetnički mentalitet dikciji pesnika čiji je jezik drugačiji, a svet već dugo nepostojeći. Prepev stvara imaginarni svet koji se sa realnim ukršta na nekoliko mesta, ali postoji nezavisno od njega. Prepev, kako me je naučio profesor Kostić, pitanje je Boga i kompleksne špekulacije talentima. Za njega nije dovoljno biti dobar prevodilac, govorio je on, jer prevođenje poezije ne podleže pravilima prevođenja proze, niti se može do kraja naučiti. Ali nije dovoljno ni biti pesnik, čak ni onaj koji odlično poznaje jezik originala ${ }^{11}$. Pesnici retko ulažu rad i trud u tuđu poeziju, retko imaju

10 "..living here / As one between two massive powers I live // Whom neutrality cannot save /Nor occupation cheer. // Move then with new desires, - For where we used to build and love - Is no man's land, and only ghosts can live - Between two fires."

11 Odličan primer suprotnog slučaja, gde pesnik nije poznavao strani jezik dovoljno dobro, ali je, uz saradnju sa onim ko je jezik poznavao, jeste prepev Šekspirovih 
„dobro uvo” i retko su vični formalnim, matematičkim aspektima versifikacije. Na kraju, treba osećati stvaralačku strast, povišeno stanje uma, o kome je pisao Platon.

Ali ko se bez nadahnuća Muza približi dverima pesničkoga stvaralaštva, misleći da će moći svojom veštinom postati valjan pesnik, taj ostaje šeprtlja, i njegovu poeziju, kao razumsku stvar, pomračuje poezija onoga koji peva u zanosu. (FEDAR 2002: 97)

- Kad pesma raspolovi glavu

pritisne rebra

zasedne, utrnula, u palčevima

kad iskoči iz tostera

vreba u orgazmu

sedi na šefovom licu

ima nade

ali

...ako joj udar

dočeka jastuk prebrajanja

ako joj ubod

pređe u pevljivost prepoznavanja

tad zauvek je otišla. (Kambaskovic-Soers 2006)

Ali ni inspiracija nije dovoljna. Dobar prevodilac poezije može biti samo onaj - ovo je najvažnije od svega - ko ima sve ove sposobnosti, a uz to je izdržljiv kao magarac i sposoban za rad na duge staze. Onaj ko je i nesebičan, i umetnik, i veliki radnik. Takvih je veoma malo. Prevodilac poezije mora biti sposoban da voli tuđu poeziju više od sopstvene, i da joj posveti život, a za malo poštovanje i još manju platu. „Najteže je to”, govorio je profesor Kostić, „što kod onih koji se trude,

soneta Stevana Raičkovića, ostvaren u saradnji sa profesorima katedre za Anglistiku. Viljem Šekspir, Soneti, prepevao Stevan Raičković, Beograd: Prosveta - Svetski klasici, 1966. 
i najveći trud često urodi u najbolju ruku osrednjim rezultatom. Zato je bolje prevesti stih pošteno, kvalitetnom prozom, ako je to potrebno za nastavu ili naučni rad, nego pokušavati s prepevom ako za to nema osnova”. On sam odbijao je da prepeva i najkraći stih, ali je odlično razumeo mukotrpan rad na metrici, i bio izvanredan kritičar. Nikad nije, za razliku od mnogih, prevodiocu davao sugestije za stilske promene koje narušavaju shemu rime ili imaju previše slogova.

Na katedri za Anglistiku ranih devedesetih, prisustvo vrhunskog prepeva uzimano je zdravo za gotovo. Poeziju su prevodili profesori Tihomir Vučković, Svetozar Ignjačević i mnogi drugi, ali priznati doajeni bili su i ostali profesori Ranka Kuić i Boris Hlebec. Uticaj prepeva engleske romantične poezije profesorke Ranke Kuić, koja je otišla u penziju upravo kad je naša generacija počinjala, uveliko se oseća $^{12}$. Profesorka Kuić nije zazirala ni od popularnih prepeva: sećam se svog čuđenja kad sam ustanovila da su prepevi tradicionalnih dečjih pesmica u narandžastom tomu četvorotomne zbirke Diznijevih priča, na kojoj su deca moje generacije praktično odrastala, izašli iz njene radionice ${ }^{13}$. Ali vrhunsko dostignuće, i danas gotovo mitskog statusa, ostaje prepev kapitalnog dela srednjevekovne književnosti, Kanterberijskih priča Džefrija Čosera, iz pera profesora Borisa Hlebe$\mathrm{ca}^{14}$. Profesor Hlebec prepevao je ovo delo, stotine stranica pisanih na srednjevekovnom engleskom pre otkrića štampe, laganim i prirodnim rimovanim dvostihom, koji kao da je pisan na modernom srpskom. Trijumf uloženog vremena i kvalitet rezultata gotovo su neshvatljivi normalnom ljudskom mozgu. Neshvatljivi su i onim mozgovima koji su, kao moj, zainteresovani za prepev. Najneverovatnije od svega je to što je, znali smo, profesoru Hlebecu prepev bio usputna delatnost:

12 Ranka, Kuić, Viljem Batler Jeits, izbor i prevod, Beograd: Mlado Pokolenje, 1971; Ranka, Kuić, Antologija engleske romantičarske poezije, uvodni esej, izbor, prevod, beleške i komentari, Beograd: Naučna knjiga, 1974.

13 Ranka, Kuić, Engleske dečje pesmice, Priče iz raznih zemalja, narandžasta knjiga, Čudesni svjetovi Walta Disneya, 1-4, Beograd: Vuk Karadžić, 1989.

${ }_{14}$ Boris, Hlebec, prevod i objašnjenja, Džefri Čoser, Kanterberijske priče, Srpska književna zadruga, 1983; Boris, Hlebec, Opšta načela prevodenja, Beograd 1989. 
on nas je, kao profesor fonetike, naučio da govorimo engleski kako treba, i bio prevashodno nastavnik mimikrije. Bez njega bih danas, u svom anglofonom životu, bila nesvesna važnosti rečeničnog naglaska, i dalje, izgovarajući englesko T (alveolarno) kao srpsko T (dentalno), imala balkanski naglasak. Možda je prepev i za njega predstavljao način da se prevaziđe stvarnost.

Moja najveća strast bili su Šekspirovi soneti. „Mnogi su otisci stopala oko pećine ove misterije, ali nema otisaka okrenutih ka izlazu." ${ }^{15}$ (Raleigh 1907: 22). Šekspirove sonete predavala sam studentima godinama (uglavnom izbegavajući čuveni sonet 18, koji je istina, savršen formalni primer engleskog soneta, ali ga malo čega drugog pesnički preporučuje). Dva su mi posebno draga, jer oslikavaju idealnu ljubav viđenu iz ženske perspektive u različitim životnim dobima. (Ne ulazim u to da li je Šekspir pisao iz ženske perspektive, ali lirska poezija mora se uvek čitati iz sopstvene perspektive, bez obzira na pol govornika.) To su sonet 130, koji ilustruje mladalačku ljubav, i sonet 31, koji ilustruje prirodu ljubavi u zreloj dobi. (Ova opozicija prisutna je i u dramskom opusu: mladalačka ljubav nalazi svoj izraz u Romeu $i$ Juliji, a zrela u Antoniju i Kleopatri). Sonet 130 imponuje mlađoj ženi, kojoj je važno da bude doživljena kao neobična i jedinstvena, lepa čak i onda kada njena lepota ne inspiriše tradicionalna pesnička poređenja.

Oko moje drage k'o sunce ne blista;

Od korala mnogo bleđe joj usnice;

Grudi su joj tamne naspram snega čista,

Kosa ne od zlatne, već od crne žice.

Video sam belih i crvenih ruža,

Ali takve ruže njen obraz ne boje;

I poneki miris veći ushit pruža

Nego miris daha u najdraže moje.

15 "There are many footprints around the cave of this mystery, none of them pointing in the outward direction." 
Znam da, mada volim kad govori mila,
Zvuk muzike ipak slađe uho mazi;
I ne videh nikad kako hoda vila,
Gospa mi, kad hoda, samo po tlu gazi.
Al' neba mi, moja ljubav nije bleđa
Od one što lažna poređenja ređa' ${ }^{16}$.

Sonet 31 ne spada u popularnije Šekspirove sonete i retko se citira, verovatno zbog izuzetno komplikovane i čvornovite metaforike. Opisuje trenutak kada dvoje zrelih ljudi, izmučenih iskustvom i pređašnjom boli, donose odluku da ipak ponovo, još jednom, poslednji put, uplove u rizične vode posvećenja drugoj osobi. Poistovećivanje voljene osobe sa grobom u kome živi zakopana ljubav, pomen delova sopstvenog tela koje su zapamtili prethodni ljubavnici i sopstvenih sećanja na njihove delove tela - trofeje iz ranijih veza - i različitih lica koja svi nosimo, jedna je od najsnažnijih poetskih metafora u svetskoj književnosti. Pol voljenih osoba kod Š ekspira je takođe etički irelevantan, što je prvi primer početka treće faze u evropskoj istoriji platonske filozofije ljubavi $^{17}$. Upravo ta doza nepoželjne istine, toliko nalik modernom poetskom izrazu, ono je što Šekspira razlikuje od ostalih renesansnih

${ }_{16}$ "My Mistress' eyes are nothing like the sun, / Coral is far more red than her lips' red; / If snow be white, why then her breasts are dun, / If hairs be wires, black wires grow on her head. // Ive seen roses damask'd, red and white, / But no such roses see I in her cheeks; / And in some perfumes is there more delight / Than in the breath that from my mistress reeks. // I love to hear her speak, yet well Iknow/ That music hath a far more pleasing sound; / I grant I never saw a goddess go, / My mistress, when she walks, treads on the ground: // And yet, by heaven, I think my love as rare/ As any she, belied with false compare." William, Shakespeare, Sonnet 130, prev. Danijela, Kambasković, Mostovi, 96 (1993), 289-290.

17 Prvu fazu započeo je Platon, sa svojim viđenjem da je etički superiorna ljubav ona koja je homoseksualna i konzumirana. Drugu istorijsku fazu započeli su filosofi florentinskog neoplatonizma, po kome je etički superiorna ljubav heteroseksualna i nekonzumirana. Šekspirovo viđenje uvodi treću fazu, po kojoj je pol voljenog etički irelevantan (on sam upotrebljava oba pola u svom sonetnom vencu), a konzumacija, kao kod Platona, prisutna i duhovno značajna. (Ova etička faza još je u toku istorijskog razvoja). Više o ovome u članku "'Of Comfort and Dispaire': Plato's philosophy of Love and Shakespeare's Sonnets" in Shakespeare and Emo- 
pesnika, i gotovo je neprevodiva. Nikada ne pročitam poslednju strofu ovog soneta sasvim suvog oka.

Ti si grob u kome živi zakopana ljubav,

Izvešan trofejima mojih prošlih ljubavi,

koje sve su svoje delove mene predale tebi;

Ono što pripadalo je mnogima, sada je samo tvoje.

Voljeno sećanje na njih sad nalazim u tebi,

A ti - svi oni - sada poseduješ sve delove svih mojih obličja ${ }^{18}$.

Šekspirovi i drugi renesansni soneti ostavili su dubok trag u mom naučnom radu i duhovnom životu. Doktorsku tezu, „Dvostruka karakterizacija i romaneskni impuls u sedam sonetnih venaca italijanskog i engleskog srednjevekovlja i renesanse" pisala sam sa prvenčetom na grudima. Oslanjala sam se na Šekspirove sonete kao krunski dokaz za moju tezu da pisci sonetnih venaca, koji su pisali uglavnom pre pojave romana, namerno stvaraju dvostruke, nestabilne glavne likove („govornike”) da bi izazvali identifikaciju čitaoca i zainteresovali ga za čitanje čitavog venca (a ne samo individualnih pesama). Ova potreba da se venac učini interesantnim i da se izgradi narativ od individualnih pesama otkriva romanopisački impuls i ostavlja mogućnost da su sonetni venci, svojevremeno čitani u celosti, imali važnu ulogu u istorijskom razvoju romana (vidi: Kombaskovic-Sawers: 2010; Kombaskovic 2015; Kombaskovic-Schwarz, 2018).

Profesor Kostić hrabrio me je u mojoj težnji da se bavim prepevom. Bilo mi je 22 godine kad sam mu prvi put donela u kabinet stihove prepevane jednog popodneva zelenom hemijskom na špartanom papiru, sedeći na stepenicama u Studentskom parku, iz ofucane fotokopije Harisonove Antologije engleske poezije, po kojoj smo radili na

tions, ed. Bob White, Mark Houlahan and Katrina O'Laughlin, London: Palgrave, 2015, 17-22.

18 "Thou art the grave where buried love doth live, / Hung with the trophies of my lovers gone, / Who all their parts of me to thee did give, / That, due of many, is now thine alone: / Their images I lov'd I view in thee, / And thou (all they) hast all the all of me". William, Shakespeare, Sonnet 31. 
fakultetu (Harrison, 1953). Neki od tih prepeva, par soneta i Herikova „Korina”, kasnije su objavljeni (u Mostovima 1993), neki nisu. Kasnije sam prepevala nešto Drajdena (vidi: Kambaskovic 1994: 6), „Šarenu lepotu” Džerarda Menlija Hopkinsa, „Ljubavnu pesmu Alfreda Dž. Prufroka” T. S. Eliota i još nekoliko Šekspirovih soneta; ništa od toga, opet, nije objavljeno (nisam mogla time da se bavim na daljinu, budući da patim od hroničnog odsustva „veza” u književnim časopisima, što je celu stvar činilo gotovo nemogućom). Posustala sam. Sekspirovih soneta ima 154; ako bi se prepevao jedan mesečno, proces prepeva trajao bi deset godina. Naravno, da sam počela u svojim dvadesetim, završla bih do svojih tridesetih; ali tada mi se to činilo nezamislivo dugim periodom. (I dalje mi se takvim čini.) Zaturila sam te prepeve i nisam im se nikad vratila. Ponovila sam pokušaj u svojoj 35. godini, kada mi se profesor Kostić (s kojim sam, uprkos internacionalnom životu, delila jedno od onih čudesnih, neobjašnjivih međugeneracijskih prijateljstava koja ponekad obasjaju ljudsko bitisanje) ponovo javio povodom izlaženja nekoliko mojih prepeva u eseju o Šekspirovim sonetima u Srbiji iz pera prof. Zorice Bečanović Nikolić, koji je trebalo da izađe u zbirci eseja o recepciji Šekspirovih Soneta u Evropi Manfreda Pfistera (Bečanović, 2009) i urgirao da ne odustanem. Opet sam prevela nekoliko soneta, tek da se podsetim zadovoljstva versifikacije i ubedim sebe kako to još uvek znam da radim; pa opet odustala. Narednih godina, tu i tamo prevela bih po koji, pa batalila. Ti prepevi raštrkani su po papirima i starim hard-diskovima nošenim kroz pustinju i prašumu, i biće potrebna ciljana komandoska ekspedicija da se nađu. Kada sam poslednji put videla profesora Kostića, u septembru 2016, ne znajući da mi je to poslednji put - kao i gubitak roditelja, gubitak profesora Kostića bio je jednostavno nezamisliv - pitao me za prepeve i tražio da obećam da ću ih sakupiti i završiti do kraja svog života. Očito je da je smatrao prepev, meni naizgled usputnu delatnost, važnijom od svih mojih ostalih, naoko važnih delatnosti. (Ni do danas ne znam da li se to u stvari može doživeti kao kompliment.) Ali to sam mu tada obećala. Gubici su sve brojniji, a najvažniji taj što sam nedavno izgubila majku, i, njenim nestankom, oslonac i osećaj doma u Beogradu. 
Sagledavam da stvari, za koje sam verovala da su večne, to nisu, i da se i moj život, sad u poslednjoj četvrtini četvrte decenije, polako kreće ka svom kraju. Vremena, koje sam nekada smatrala beskrajnim, imam sve manje, a projekata sve više. Profesora Kostića više nema, prepevi su zatureni. Sekspirovi soneti poprimaju mitske dimenzije, i dozivaju me noću. Osećam da je obećanje dato profeoru Kostiću jedno od najvažnijih obećanja koje sam dala u životu, i ne smem ga prekršiti. Vreme prolazi.

\section{ZUB VREMENA: NAGRIZANJE I OČUVANJE}

Pitanje koje je zaokupljalo Petrarku, Šekspira i ostale pesnike i umetnike srednjevekovlja i renesanse (a pre njih, antičke filozofe) bilo je pitanje umetničke besmrtnosti, ili bar dugovečnosti. Svesni kratkotrajnosti ljudskog veka, smatrali su da nema neke veće svrhe živeti na Zemlji, a ne učiniti pokušaj da se tvorevinom produži sopstveni vek. Po Platonu, to se može učiniti prokreacijom ili kreacijom proizašlom iz ljubavi: kreacija pruža viši vid ostvarenosti (Platon 2002, Fedar 209c). Prokreacija kao vid produženog života tema je koja zaokuplja Šekspira u prvih sedamnaest soneta, dok pitanje važnosti besmrtnosti postignute kreacijom - na svojstven način kombinovane sa postulatima Platonove filosofije ljubavi - promiče kroz preostale sonete kao reka ponornica.

Znamo da zub vremena nagriza i uništava mnogo više umetničkih dela nego što je onih čiju vrednost potvrđuje, ali pesnik, u zatvoru sopstvene perspektive i vremena, ne može znati kojim će se putem kretati njegovo delo. Može, po ugledu na Horacija ${ }^{19}$, gordo iskazivati uverenost u sopstvenu superiornost:

19 Horatius Flaccus, “Exegi monumentum aere perennius” („Podigao sam spomenik trajniji od bronze”), Odes IV and Carmen Saeculare, Cambridge: Cambridge University Press, 2011. 
Kao što talasi obali hitaju

I minuti naši svome kraju žure;

Oni davno prošli mesto ustupaju

Onima što slede, a svi napred jure.

I sav sjaj i blesak čovečjeg rođenja

Ka zrelosti stremi, i kada je stekne,

Zaklone ga crna, podla pomračenja -

Darodavac vreme darove porekne.

Vreme gasi vrele mladenačke vatre,

I sklad uništava što lepota nosi,

Od prirode date posebnosti zatre,

Ničeg nema da ga ono ne pokosi;

Pa ipak se nadam, stih moj izdržaće,

Vremenu za inat tebe opevaće ${ }^{20}$.

Kvalitetno pisanje daje čoveku mogućnost da pobedi vreme u kome živi, i bude zauvek pamćen. Ništa lakše za stvaraoca, nego u onome što napiše, na manje ili više suptilan način, oglašavati sopstvenu umešnost.

Međutim - a tu je Šekspirov čvor - nema garancija da će delo koje pesnik sam promoviše zaista i postati besmrtno. Busanje u grudi je jedno, a budućnost nešto sasvim drugo. Niko ne želi da zamišlja busanje u grudi koje nakon pet stotina godina više niko ne čita. Šekspirova genijalnost je u tome što nagoveštava da je oslanjati se na horacijevsko hvalisanje rizična strategija, i svojim receptom za nezaborav odstupa od formule na način koji je vrlo upečatljiv i ne sreće se ni u

20 "Like as the waves make towards the pebbled shore/ So do our minutes hasten to their end; / Each changing place with that which goes before, / In sequent toil all forwards do contend. // Nativity, once in the main of light, / Crawls to maturity, wherewith being crowned, / Crooked eclipses 'gainst his glory fight, / And time that gave doth now his gift confound. // Time doth transfix the flourish set on youth / And delves the parallels in beauty's brow; / Feeds on the rarities of nature's truth / And nothing stands but for his scythe to mow. // And yet to times in hope my verse shall stand, / Praising thy worth, despite his cruel hand." William Shakespeare, Sonnet 60. Prepev Danijela Kambasković, „Iz engleske renesansne poezije", Mostovi, 96 (1993), 289-290. 
jednom drugom delu iz ovog perioda (i reklo bi se, izrazito je modernog senzibiliteta). Istina, on povremeno iskazuje samoudivljenje, ali ovome uvek daje zanimljivu protivtežu neodoljivim izrazom melanholije (danas zvane „depresija”), samomrzja i razočaranja svetom:

Da te svet ne bi prisiljavao da nabrajaš

Moje dobre osobine, koje bi trebalo da voliš

i nakon moje smrti - ljubavi, zaboravi me sasvim.

Ništa moje neće se pokazati kao tebe vredno.

Možda ćeš izmisliti neku laž iz dobrote i samilosti

Kojom bi mi učinio veću čast nego moje zasluge,

I okačio više hvale na mene umrlog

Nego što bi mi škrta istina dobrovoljno pripisala.

O, da tvoja iskrena ljubav ne bi izgledala lažljivo,

Jer ti, iz ljubavi, o meni govoriš lepe neistine,

Sahrani moje ime s mojim telom,

I nek ne živi više da sramoti ni tebe ni mene.

Jer ja se stidim onog što sam stvorio,

A stidi se i ti, što voliš ono što je bezvredno ${ }^{21}$.

Na svetu, pokazuje on, nema mnogo toga novog, niti mnogo toga zbog čega vredi živeti, osim ljubavi.

Umoran od svega, smrt utešnu želim

Kad zaslugu vidim ko prosjaka tužnog,

I glupu prazninu kako se veseli,

Najčistiju veru pogaženu ružno,

Čast i slavu sramno krivom dodeljenu,

Devojačku čednost grubo uniženu,

21 "O lest the world should task you to recite / What merit lived in me that you should love, / After my death, dear love, forget me quite, / for you in me can nothing worthy prove:// Unless you would devise some virtuous lie,/ To do more for me than mine own desert, /And hang more praise upon deceased I / Than niggard truth would willingly impart.// O lest your true love may seem false in this, /That you for love speak well of me untrue,/ My name be buried where my body is, / And live no more to shame nor me nor you. / For I am shamed by that which I bring forth, / And so should you, to love things nothing worth." William Shakespeare, Sonnet 72 . 
I nameru čistu zlobno ocrnjenu,

I negdašnju snagu sada oslabljenu,

I znanje, kom vlasti da govori brane,

I bahatu ludost što umeće gazi,

Istinite reči glupostima zvane,

I roba dobrotu što zlog gazdu pazi,

Umoran od svega, otišo bih lako,

Kada ljubav ne bih napustio tako ${ }^{22}$.

Ljubav je ono što čini životne nedaće podnošljivim, kao što sećanje na prošlost i nada okrenuta budućnosti čine sadašnjost boljom. Smrt najdražih podseća nas na smrt koja je i nama zapisana, a pomisao na posebne odrasle, i na odrastanje dece, tih malih ljudi koje volimo više od svega, omogućava nam da se mišlju sa njom i suočimo. Ljubav nam pomaže da ne gubimo vreme, da pustimo vreme da nas leči, da nađemo vremena. Zbog ljubavi čuvamo bezinteresne stvari koje život znače, kao što su etika, poezija, književnost, prepev, sećanje. Zbog ljubavi radimo i dajemo. Zbog ljubavi se trudimo da iskoristimo svoje vreme na najbolji mogući način, i ostavimo nešto ili nekoga iza sebe.

Ako kod tebe nema straćenog trena,

I ako radom pratiš kazaljke rad,

Tvoja je Zemlja, i sva bogatstva njena,

I više, sine: ti Covek bićeš tad. ${ }^{23}$

A da li ćemo uspeti... to je pitanje vremena.

22 "Tired with all these, for restful death I cry, / As to behold desert a beggar born, / And needy nothing trimm'd in jollity, / And purest faith unhappily forsworn, // And gilded honour shamefully misplaced, / And maiden virtue rudely strumpeted, / And right perfection wrongfully disgrac'd, / And strength by limping sway disabled/ And art made tongue-tied by authority, / And folly-doctor-like - controlling skill, / And simple truth miscall'd simplicity, / And captive good attending captain ill, // Tir'd with all these, from these would I be gone, / Save that, to die, I leave my love alone." Shakespeare, William, Sonnet 66.

23 "...If you can fill the unforgiving minute/ with sixty seconds' worth of distance run, / yours is the Earth and everything that's in it/ And-which is more-you'll be a man, my son." Rudyard Kipling, "If". 
Danijela Kambasković - Švarc: Pitanje vremena

\section{IZvORI I CITIRANA LITERATURA}

BALINT, Jennifer, et al. "Rethinking Transitional Justice, Redressing Indigenous Harm: A New Conceptual Approach”, The International Journal of Transitional Justice, Vol. U, 2014, 194-216

BeČAnovic, Zorica, "Shakespeare's Sonnets in Serbia" in William Shakespeare's Sonnets: For the First Time Globally Represented, A Quatercentenary Anthology. Manfred Pfister and Jürgen Gutsch, Dozwil (eds.), Switzerland: Edition SIGNAThUR, 2009.

Boswell, James. Life of Samuel Johnson. LL. D. New York: Alexander V. Blake, 1844.

Furness, H. H. (ed), A New Variorum Edition of Shakespeare, Othello (London: J. B. Lippincott Co, 1886), p. 358.

Harrison, G. B. (ed.) A Book of English Poetry, London: Penguin Books, 1953.

Hawking, Stephen. W., "The Beginning of Time", www.Hawking.org.uk/thebeginning-of-time.html, viđeno 19.03. 2018.

Hlebec, Boris, prevod i objašnjenja, Džefri Čoser, Kanterberijske priče, Srpska književna zadruga, 1983.

HLEBec, Boris, Opšta načela prevodenja, Beograd 1989.

Horatius Flaccus, "Exegi monumentum aere perennius" ('Podigao sam spomenik trajniji od bronze"), Odes IV and Carmen Saeculare, Cambridge: Cambridge University Press, 2011.

Kambasković, Danijela, "The sonnet sequence before early modern eyes: printing practices and notions of the genre, Italy 1450-1650", Parergon, the Journal of the Australian \& New Zealand Association for Medieval and Early Modern Studies, January 2016,

--- Prepev i beleška, „Džon Drajden, Ogled o Kritici”, Književne Novine, 1994, br. 895, str. 6.

--- Prepev, William, Shakespeare, Sonnet 60 and Sonnet 130. Mostovi, 96 (1993), 289-290.

KAMBASKOvić-Soers, Danijela, Kratka istorija australijske $i$ novozelandske književnosti, Beograd: Balkanski književni glasnik, 2015.

Kambaskovic-Sawers, Danijela, "'Of Comfort and Dispaire': Plato's philosophy of love and Shakespeare's Sonnets" in Shakespeare and Emotions, Bob White, Mark Houlahan and Katrina O'Laughlin (eds.), London: Palgrave, $2015,17-22$. 
Kambaskovic-Sawers, Danijela, Constructing Sonnet Sequences in the Late Middle Ages and Renaissance: A Study of Six Poets. Lewiston, New York: Edwin Mellen Press, 2010, hard cover.

Kambasković-Soers, Danijela, „Prepev”, Atlantida, Povelja, Kraljevo, 2006.

Kambaskovic-Schwartz, Danijela, "I am Lunaticke: Michael Drayton, Samuel Daniel and the evolution of the first person", A Companion to Renaissance Poetry, Catherine Bates (ed.), Oxford: Blackwell-Wiley, 2018.

KIPLING, Rudyard, "If", Collected Poems of Rudyard Kipling, Introduction by George Orwell: Introduction and Notes by R.T. Jones, Herts: Wordsworth Editions, 1999.

Lewis, C. Day, "The Conflict" in C. Day Lewis, San Francisco: Stanford University Press, 1992.

Kuić, Ranka, Viljem Batler Jeits, izbor i prevod. Beograd: Mlado pokolenje, 1971.

KuIć, Ranka, Antologija engleske romantičarske poezije, uvodni esej, izbor, prevod, beleške i komentari, Beograd: Naučna knjiga, 1974.

Kuć, Ranka, Engleske dečje pesmice, Priče iz raznih zemalja, narandžasta knjiga, Čudesni svjetovi Walta Disneya, 1-4, Beograd: Vuk Karadžić, 1989.

Raleigh, Walter, Shakespeare, New York: The MacMillan Company, 1907, 22.

RaǏ̌Ković, Stevan, prepev. Šekspir. Soneti, Beograd: Prosveta - Svetski klasici, 1966.

Platon, Dela (Ijon, Gozba, Fedar, Odbrana Sokratova, Fedon), prev. Miloš N. Đurić. Beograd: Dereta, 2002.

Shakespeare, William in Greenblatt, Stephen et al. (eds.), The Norton Shakespeare, Oxford: Oxford University Press, 2008, 46.

--- The Tragedy of King Richard The Second, Act 1, Scene 3, 1l. 153-64, in pp. 973-10.

--- A Midsummer Night's Dream (pp. 839-896), Act 5, Scene 1, ll. 12-17.

--- The Comical History of The Merchant of Venice, or Otherwise Called The Jew of Venice (pp. 1111-1176), Act 4, Scene 1, ll. 179-184.

--- The Tragedy of Hamlet, Prince of Denmark (pp. 1683-1784.), Act 2, Scene 2, ll. 244-5.

--- Sir Thomas More, Act 2, Scene 4, ll. 55-124

--- The Sonnets (pp. 1937-1999)

--- Sonnet 66

--- Sonnet 72

--- Sonnet 94 
Sproule, Albert Frederick, "A Time Scheme for Othello" in: Shakespeare Quarterly, Vol. 7, No. 2 (Spring, 1956), pp. 217-226.

UNKNOWN, "Once considered a boon to democracy, social media have started to look like its nemesis.", The Economist, November 2017, https:/www. economist.com/briefing/2017/11/04/once-considered-a-boon-to-democracy-social-media-have-started-to-look-like-its-nemesis

Danijela Kambasković-Schwartz

\section{A QUESTION OF TIME}

Summary

This paper examines the idea and the effects of the passage of time from the perspectives of physics, literary history and personal history, in order to celebrate the methods of textual criticism, literary history, poetry translation and history of ideas taught at the Department of English, Faculty of Philology, University of Belgrade, amidst the political turmoil of the early 1990s.

Keywords: time, physics, literary history, personal history, transliteration.

Univerzitet Zapadne Australije

danijela.kambaskovic-sawers@uwa.edu.au 